\title{
TV/Series
}

1 | 2012

Les Séries télévisées américaines contemporaines :

entre la fiction, les faits, et le réel

\section{Transforming the traditional sitcom: Abed in \\ Community}

Shannon Wells-Lassagne

\section{OpenEdition}

\section{Journals}

Electronic version

URL: http://journals.openedition.org/tvseries/1560

DOI: 10.4000/tvseries. 1560

ISSN: 2266-0909

Publisher

GRIC - Groupe de recherche Identités et Cultures

Electronic reference

Shannon Wells-Lassagne, "Transforming the traditional sitcom: Abed in Community ", TV/Series

[Online], 1 | 2012, Online since 15 May 2012, connection on 10 December 2020. URL : http://

journals.openedition.org/tvseries/1560; DOI : https://doi.org/10.4000/tvseries.1560

\section{(c) (i) (9)}

TV/Series est mis à disposition selon les termes de la licence Creative Commons Attribution - Pas d'Utilisation Commerciale - Pas de Modification 4.0 International. 


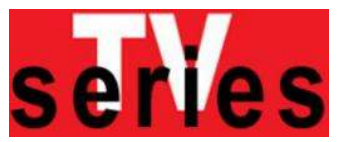

\title{
Transforming the traditional sitcom: Abed in Community
}

\author{
Shannon WELLS-LASSAGNE
}

\begin{abstract}
At first glance, NBC's freshman comedy Community appears to be the perfect example of a high-concept sitcom: the main character Jeff Winger is a lawyer who has been disbarred for fake diplomas, and who therefore has to go back to school at a community college in order to regain his job. He is surrounded by fellow students, the stereotypical misfits that people sitcoms: the matronly single black mother, the uptight overachiever, the dumb and arrogant jock, the attractive hippy (and love interest), and the retiree going back to school, whose cluelessness is butt of the majority of the jokes. However, a final character, Abed, seems almost extraneous to the proceedings: he is a half Polish, half Palestinian film student, who suffers from Asperger's and therefore has a difficult time understanding the relationships around him. Like Pierce, Abed would seem to be the odd man out, the source of much of the humor for the series; but in fact he serves an entirely different purpose. As a film student who was "raised by television", Abed is constantly comparing events in the episodes to films and television series, thus immediately identifying the group as "The Breakfast Club" in the pilot episode, or proving capable of flirting with the opposite sex only when channeling Don Draper of Mad Men fame. This could be seen as a simple nod to the formulaic nature of the sitcom, an ironic wink to the viewer, but as the series progresses, Abed and his pop culture references take on increasing importance. His knowledge of genre rules becomes an almost divinatory power: once he begins taking film classes, his shorts about the group of friends actually predicts the future of the series, foregrounding the predictable nature of the sitcom action and taking it to task. Abed's love of popular culture slowly becomes the raison d'être of the series, as each episode seems to become one of his renditions of film genres. In so doing, the character points out the artifices of the sitcom genre, while at the same time transforming the mundane into the spectacular, insisting on the elements of fiction that appear in our everyday lives: through Abed, Community both reifies sitcom conventions and links them back to the spectator's own lives - making it one of the most original series in recent memory.
\end{abstract}

$\mathrm{T}$

There is of course a reason that sitcoms are underrepresented in academic circles when discussing television': as a rule they are less visually rich, having lower budgets than their more esteemed dramatic counterparts, and in terms of content, they are much more normative and conservative than other television genres, oftentimes

${ }^{1}$ There have been some significant contributions, but these are limited when compared to the multitude of works devoted to television in recent years, and book-length studies (Antonio Savorelli, Beyond Sitcom: New Directions in American Television Comedy, Jefferson, NC, McFarland, 2010; The Sitcom Reader: America Viewed and Skewed, Mary M. Dalton, Laura R. Linder, eds., Albany, NY, State University of NY Press, 2005; Brett Mills, The Sitcom, Edinburgh, Edinburgh UP, 2009; Critiquing the Sitcom: A Reader, Joanne Morreale, ed., Syracuse, NY, Syracuse UP, 2003) have only appeared in the last ten years. 
creating stock characters and situations that favor the quick laugh rather than any deep insight, and impede much hope of inventivity. Whether this can be attributed to the sitcom's close affiliation with broad comedy, whether it be slapstick or commedia dell'arte, its restrictive format, or its very commercial nature (in the past few decades, sitcoms have traditionally been the biggest hits for networks, something that has become obvious to the general public recently with CBS's excessive tolerance of Charlie Sheen's shenanigans in order to keep their hit sitcom Two and a Half Men (CBS, 2003-) afloat ${ }^{2}$ ), the fact is that the situation comedy tends to exacerbate television's tendency towards stock situations, and easy and moralistic resolutions to all crises ${ }^{3}$.

In other words, the sitcom is generally not what is most interesting to academics analysing the possibilities of television, and especially not to those who want to examine TV fiction's relationship to reality, with notable exceptions like Taxi (ABC, 1978-1982, NBC 1983), Cheers (NBC, 1982-1993), and more recently The Office (NBC, 2005-). I hope to show that Community (NBC, 2009-) also figures among its exceptions, again both in terms of form and content. Paradoxically, it does so by embracing the stereotypical, unrealistic nature of the sitcom, and turning it from traditional comedy to metacommentary on the format.

The premise of Community is simple: the sitcom's title is short for community college, and at first glance, it appears to be the perfect example of a high-concept sitcom: the main character Jeff Winger is a lawyer who has been disbarred for fake diplomas, and who therefore has to go back to school at a community college in order to regain his job. He is surrounded by fellow students, the stereotypical misfits that people sitcoms: the matronly single black mother, the uptight overachiever, the dumb and arrogant jock, the attractive hippy

${ }^{2}$ The Daily Beast has a summary of Charlie Sheen's antics while he was still the leading character on the show ("Charlie Sheen, Two and a Half Men, and the Hollywood Machine", http://www.thedailybeast.com/articles/2011/01/28/charlie-sheen-two-and-a-half-menand-the-hollywood-machine.html). The articles on his behavior are innumerable. Sheen went on to insult the show's producer, Chuck Lorre, and the series was then cancelled for the rest of the eighth season " Charlie Sheen's rants against boss prompt cancellation of Two and a HalfMen season", http://articles.latimes.com/2011/feb/25/entertainment/laet-charlie-sheen-shut-down-20110225), before Sheen's character was killed off and the actor was replaced by Ashton Kutcher in the ninth series' premiere ("Killing Charlie Sheen character a 'thrill' for Two and a Half Men creator",

http://www.suntimes.com/entertainment/zwecker/684.3400-4.52/killing-charlie-sheencharacter-a-big-thrill-for-two-and-a-half-men-boss.html). (All articles consulted October 2011.)

3 Even those seeking to validate the sitcom acknowledge its assumed limitations, as can be seen in Joanne Morreale's introduction to Critiquing the Sitcom: "While their status as commercial products suggests that they will ultimately support the status quo, they may also allow for a multiplicity of discourses. Although their formulaic nature may appear to limit the implications of the debates they engender, many sitcoms allow for contradictory readings." (Joanne Morreale, Critiquing the Sitcom: A Reader, op. cit., p. xii) 
(and love interest), and the retiree going back to school, whose cluelessness is butt of the majority of the jokes. Indeed, the opening sequence of the series reinforces the idea that they are all simple stereotypes, as the Dean's welcoming speech suggests that the community college is frequented by different brands of easily dismissed "losers" while the camera focuses consecutively on several of the principal characters in the series to come:

DEAN: What is community college? Well, you've heard all kinds of things. You've heard it's "loser college" for remedial teens, twentysomething dropouts, middle-aged divorcées, and old people keeping their minds active as they circle the drain of eternity. That's what you've heard; however, I wish you luck!... OK, uh-oh, you know what, there's more to this speech, there's actually a middle card missing. (1.1, 0-2:09)

However, a final character, Abed, seems almost extraneous to the proceedings, completely set apart from the other broad stereotypes traditional in a sitcom: he is a half Polish, half Palestinian film student, who may suffer from Asperger's and therefore has a difficult time understanding the relationships around him. In other words, the writers have purposefully made the character as unrelatable as possible to the general audience. One might initially think that Abed would serve a purpose similar to retiree Pierce, seemingly the odd man out and the source of much of the humor for the series; but in fact he serves an entirely different purpose. As a film student who was "raised by television", Abed is constantly comparing events in the episodes to films and television series, thus immediately identifying the group as "The Breakfast Club" in the pilot episode, or proving capable of flirting with the opposite sex only when channeling Don Draper of Mad Men fame (the writers compound this pop culture reference by making the girl he flirts with actress Alison Brie, who plays Trudy in Mad Men). 


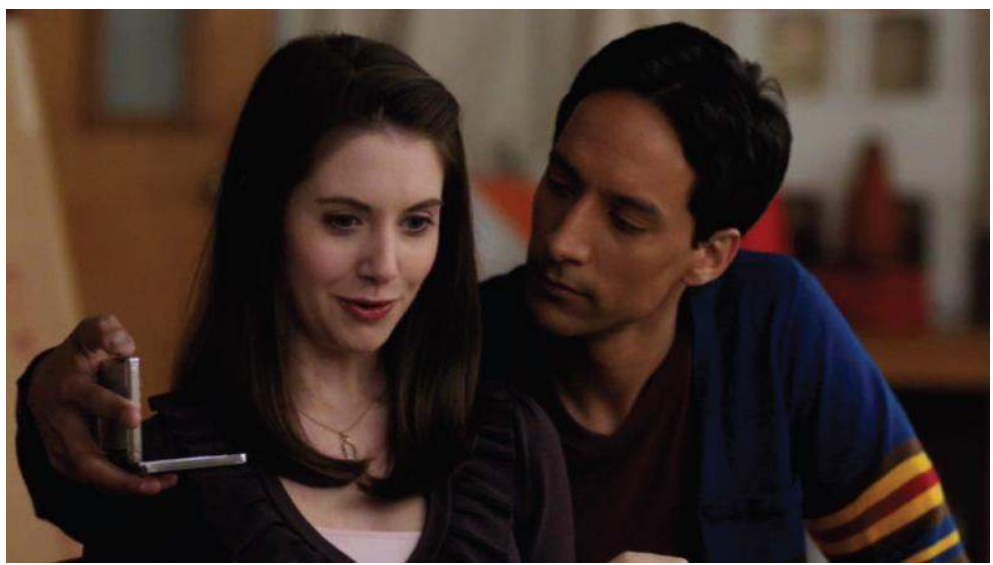

Plate 1: Abed (Danny Pudi) "doing” Don Draper while flirting with Annie (Alison Brie)

I will be focusing on this character, then, in order to analyze the way in which he represents Community's unique status as a sitcom, and the way that it calls its very genre into question.

Of course we know that one of the ways that television draws its viewers in is through its immediacy, for example in the holiday episodes that make us feel that the diegetic world of the series is taking place simultaneously with our own. In this sense, Community has simply found a new means to convey that proximity to the audience, through pop culture. Likewise, Community is neither the first nor the last to use pop culture references to make the world of the series more recognizable to the viewer - I would argue that this began in earnest with the success of the animated series The Simpsons (Fox, 1989-), and became the calling card for series like Buffy the Vampire Slayer (Fox, 1997-2003), a touchstone to link the viewer to settings that might otherwise seem a bit too outlandish for the viewer, be it the fantastical world of Sunnydale or the animated town of Springfield. However, I would argue that the evolution of the phenomenon, its breadth, as well as its defining purpose, make it worthy of notice.

The series makes it very clear at the outset that Jeff is to be our focal character: he is a newcomer to the college, and his introduction to the setting and the characters are also ours. Jeff is a jaded hipster, by turns annoyed and amused by the ragtag team by which he is surrounded, and the pilot makes a point of contrasting his "normalcy" with the bizarre natures of the other characters. He dominates both the conversation and the action, though this superiority is tempered by a few rebellions (notably Britta's refusal to date him and his friend and (now) professor Duncan's refusal to give him all the exam answers); this is both a ploy to continue interaction 
between the characters and a proleptic tool suggesting the "life lessons" that he (and we) are to learn. In interviews, Dan Harmon, series creator and showrunner, recognized that Jeff is in fact a version of himself, based on a personal experience of trying to save a relationship by attending a community college with a girlfriend (on whom the love interest, Britta, is based) and becoming involved in a study group there, both academically and personally:

AVC: So you're the Joel McHale character?

DH: Yeah. You know, he's definitely the televised version of me. [Laughs.] There's a scene in the pilot where he's on the football field with John Oliver and he says, "I discovered when I was a kid that if I talk long enough I can make anything right or wrong." That sums up what I was feeling at that community college. I had spent all of my life empowering myself, proving I was a big boy and could do whatever I wanted. But that's only half of a life. So, in that respect, the character is me. But at this point it's just Joel McHale saying stuff 4 .

As such, Joel McHale's Jeff was originally supposed to reflect the viewer: a cynical character who slowly discovers the value of friendship with the most unlikely people. Abed, we are told, was simply to play off that cynicism:

Abed was always a commenter in the beginning [...] He was sidekick kind of a character. But that was there as a safety valve for anybody who was so sick of TV and didn't trust it anymore. Here he was a fan of everything in the past and also now a fan of what you were watching with him5.

Abed's sincere love for all things fictional served to counteract any feelings of disillusionment with the format, and to acknowledge its formulaic nature, as for example in the second episode of the series, where his commentary on the Dean's announcements invites us to acknowledge the realism of talking about television conventions, all while poking fun at them:

ABED: I like it. It makes every ten minutes feel like the beginning of a new scene of a TV show. Of course, the illusion only lasts until they say something they'd never say on TV - like how much their life is like TV. There, it's gone. (1.2, $0-0: 57)$

Initially, then, Abed's references to pop culture were intended to

4 "How Dan Harmon went from doing ComedySportz in Milwaukee to creating NBC's Community", http://www.avclub.com/milwaukee/articles/how-dan-harmon-went-fromdoing-comedysportz-in-mil,34126/, consulted January 2011.

5 "'Community': EP Dan Harmon explains Abed's evolution", http://blog zap $2 i t$ com/frominsidethebox/2010/11/community-ep-dan-harmon-explainsabeds-evolution.html, consulted January 2011. 
increase the verisimilitude of the series: like us, Abed watches TV, knows the norms of the TV series, and remarks on it when it happens thus suggesting that it does happen "for real", and not just on TV. Abed is relatable to the audience, not in terms of race, or class, or personality, but as a fellow consumer of fictions.

Of course, since this is not a habit of the sitcom, these references to TV being like TV are both defamiliarizing and distancing - we may appreciate the sitcom anew, but of course we are also thrown out of the suspension of disbelief one generally affords fiction, however briefly: "There, it's gone," as Abed would say.

However, this initial role, a simple nod to the formulaic nature of the sitcom, an ironic wink to the viewer, soon evolved: as fans reacted to Abed, as the writers identified with him, Abed and his pop culture references take on increasing importance. Rather than simply throwing out occasional remarks on television tropes, whole episodes become homages to genres, and often this is because Abed actually creates the parody, as in Season 1's "The Science of Illusion”, where he imitates all hard-ass sergeants from buddy cop movies to set Annie and Shirley at odds in their duties as volunteer security at the campus (1.20, 14:00-15:04 ${ }^{6}$ ). Clearly, Abed sees things only in terms of fictional genres, and his hankering for fiction slowly comes to take over the world of the show as a whole. No doubt the best example of this is in Season 2's Christmas episode, where Abed's belief that everyone is in fact suddenly made up of Claymation in fact causes the viewer to suddenly witness everything from his perspective, and the characters become Toys worthy of the Island of Misfits in the classic Rudolph the Red-Nosed Reindeer Christmas special by Rankin-Bass.

${ }^{6}$ http://www.youtube.com/watch?v=GTcavNQgct4 


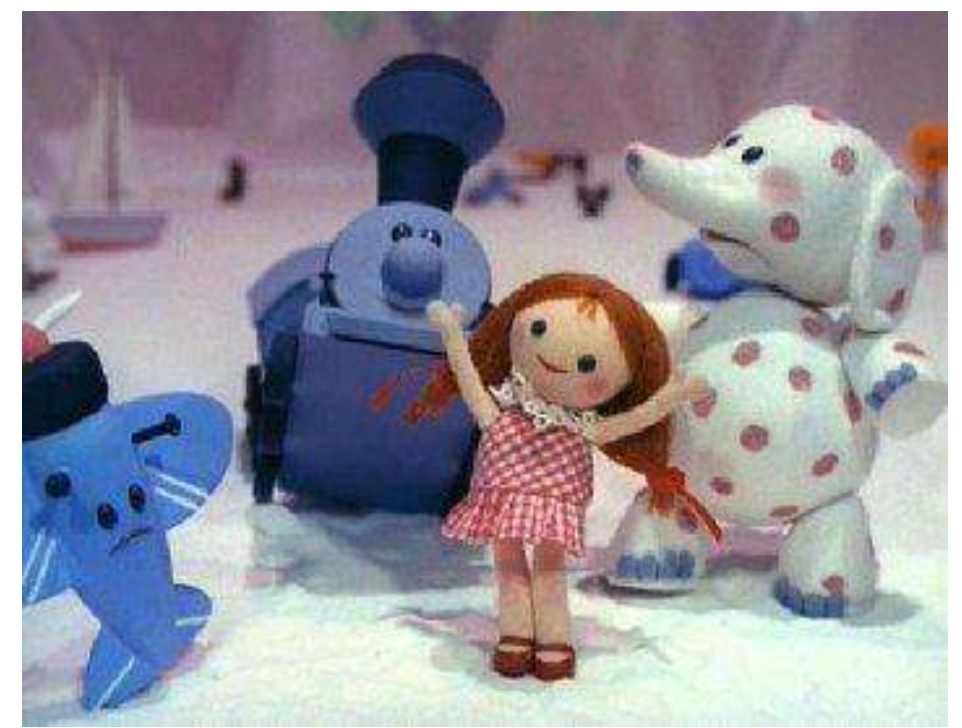

Plate 2: Rankin-Bass's classic Claymation "Island of Misfits" sequence

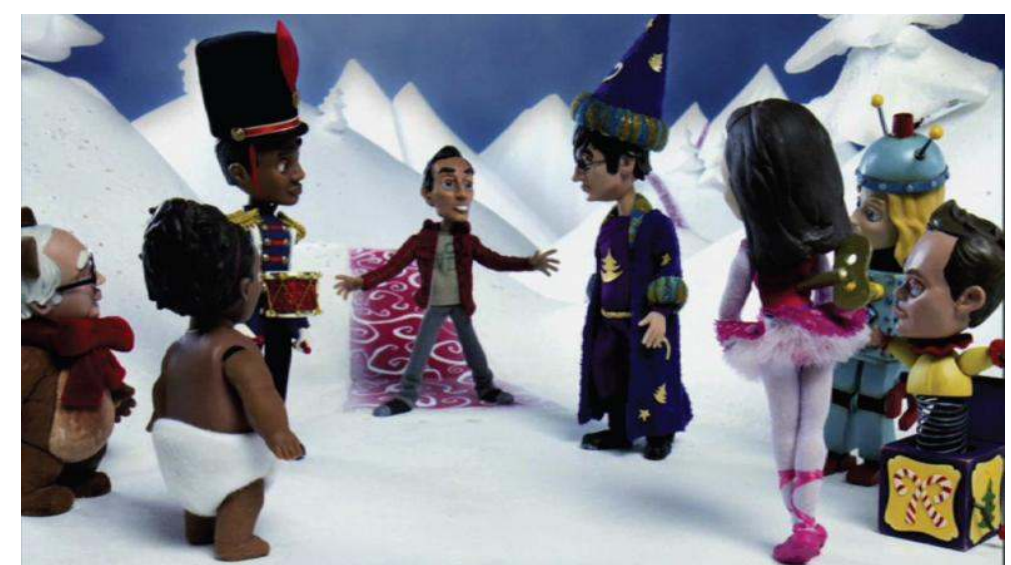

Plate 3: Abed's vision of a land of Christmas: "Abed's Uncontrollable Christmas" (2.11)

A later episode, "The Paradigms of Human Memory", which spoofs another sitcom standby, the clip show, in fact shows us the reality of the situation: the entire group is sitting around the library table, halfheartedly responding to Abed's ravings (2.21, 3:47-4:10) Here, clearly, 
we are seeing things from Abed's perspective - he has become our focal point.

Though this is of course played for comedic effect in the series, the fact remains that beyond the extended reference to genres, Abed is repeatedly able to explain the behavior of the series' characters through his knowledge of television, as in "Communications Studies" (1.16), where Britta drunk dialing Jeff is explained in terms of Chandler seeing Rachel naked in Friends. The series goes further - when Abed makes films, his role as a keen observer of life, fictional or otherwise, becomes an almost divinatory power, since his short films about the group of friends actually predicts the future of the series (to the disbelief of the other characters):

TROY: Have you seen the film department's website?

JEFF: What do you think? [Troy opens laptop to website]

TROY: All of Abed's films are about us. Check it out.

[On computer screen, dialogue between characters that repeats the previous week's episode]

BRITTA: Those people look just like us; that's eerie. [...] We had almost that exact conversation last week.

TROY: Yeah - but Abed posted this video two weeks ago.

SHIRLEY: That boy's a soothsayer.

TROY: This is wrinkling my brain.

FAKE TROY [on computer screen]: This is wrinkling my brain.

TROY: That's wrinkling my brain! (1.9, 1:27-2:19)

This is of course an absurd version of David Foster Wallace's argument that TV has become a source of inspiration - as examples of the human condition - for today's writers7. As such, the joke is also a self-critique, foregrounding the predictable nature of the sitcom action and taking it to task.

All of this of course is not just due to Abed. Many times, Abed simply calls attention to the parody implicit in the action. For example, in a season two episode entitled "Cooperative Calligraphy", he announces that a bottle episode - an episode where the characters are stuck in an enclosed space together for the length of a show - is imminent when no one comes forward to admit that they stole Annie's pen. It is Jeff who finally makes the decision to put the group on lockdown:

JEFF: Lockdown! Abed, seal the doors! Nobody leaves 'til this pen shows up!

ABED: I don't like this.

JEFF: Yeah, well, tell that to the pen you might have. [on phone] Gwynnifer! Hi, it's me, I can't make it. Well, tell your disappointment to suck it. I'm doing a bottle episode! (2.8, 8:35-8:54)

7 David Foster Wallace, "E Unibus Pluram: Television and U.S. Fiction”, Review of Contemporary Fiction, Vol. 13, No. 2, 1993, p. 151-194. 
Some of the most memorable referential episodes like "Modern Warfare", an episode where a paintball game occasions a spoof of action movie tropes, are not inspired by his actions.

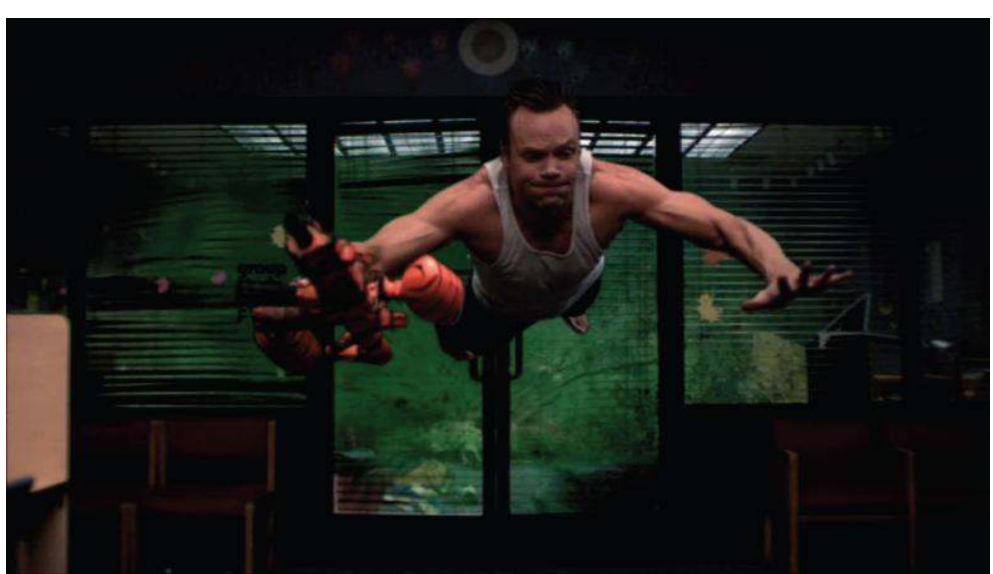

Plate 4: Diving away from an explosion... of paint.

However, it is no coincidence that the character of Abed takes on increasing importance as the sweep of the referential tropes increase. In fact, in later interviews Dan Harmon admitted that he now identified with Abed:

"I'm really more identifying with Abed and becoming him more. He's me now in many ways. Everybody has some kind of trait that I am making fun of about myself. But Abed really kind of has a lot in common with me, so that's really all I can say. He is sort of the umbilical point through which the writers are able to be invested in the show ${ }^{8}$."

Indeed, when we look at the character carefully, we see that he represents both fiction and those who create it: he is a master manipulator, willfully provoking the ire of the other characters when making his films, and even charting the female characters' cycles to know when to have chocolate or tissues on hand to ward off arguments. Clearly, he is writer and director not only of his own films, but of the diegetic world we're observing. Likewise, his status as consumer and fan of fiction and his subsequent ability to influence reality is echoed in the series' own efforts to make the series more "real" to the audience through interaction with fans: thus on NBC's website, it's possible to find both Abed's films and the pop culture course he would teach if he

${ }^{8}$ Community': EP Dan Harmon explains Abed's evolution, op. cit. 
were in charge of the college campus. Likewise, the "Gwynnifer" that Jeff calls to cancel his date in "Cooperative Calligraphy" is in fact the name of a frequent and frequently critical poster on the show's twitter page $^{9}$ - the metafiction of the "bottle episode" reference is linked to the inside joke, and both are intended to once again both increase the proximity to the spectator while acknowledging its fictional status.

The question, of course, is how far can this go? In "Contemporary American Poultry", we see two turning points for the series - it is the first completely Abed-influenced episode, where the homage is essentially his doing, and more diegetically, we have Abed taking over Jeff's place as unofficial head of the dysfunctional family. The episode deals with the eternal quandary of a lack of chicken fingers at the cafeteria, and Jeff's suggestion that they get Abed a job as fry cook in order to reserve some for themselves. This becomes a rendition of Goodfellas in Abed's head, complete with voiceover explaining the inner workings of "The Family" overlaid with a medley of crooner songs (1.21, 6:40-7:35), and generally spoofs the mafia genre. Like all mafia movies, however, the characters are corrupted by their newfound power, and Abed eventually turns in his apron (at Jeff's behest).

Afterwards, this rivalry for power between Abed and Jeff becomes a recurrent theme, in essence encapsulating a rivalry between the classic sitcom plot that Jeff represents (the jaded character brought to understand his big heart through interaction with the other characters) and metacommentary, especially during the second season, where Abed's function - and the series' referential humor - has been well established. Season 2 begins with the new school year, and Abed tallying up the possible sitcom scenarios they could use in the new season:

ABED: Hey Jeff, do you have any hillbilly cousins?

JEFF: I wish. Why?

ABED: How about a wealthy uncle. Or an old drinking buddy that may or may not have had a sex change?

JEFF: Abed, why are you mining my life for classic sitcom scenarios?

ABED: I guess I'm just excited for the new year, looking for ways to improve things. I'm hoping we can move away from the soapy, relationshippy-stuff and into bigger, fast-paced self-contained escapades. $(2.1,5: 36-5: 52)$

before he finally gives into the "soapy relationshippy stuff" and sets up an engagement and a wedding, complete with a George Clooney impersonator as best man, while Jeff eventually screams at him in frustration:

9 "Replying with the Enemy: Showrunners on Twitter II", http://blog.commarts.wisc.edu/2010/11/11/replying-with-the-enemy-showrunners-ontwitter-ii/, consulted March 2011 
JEFF: Oh, good, yeah, cancel us. And while you're at it, why don't you take your cutesy, "I can't tell life from TV" gimmick with you. You know, it's very "Season 1". (14:52 - 15:08)

This struggle for the audience's focus becomes more prevalent in season two, with Jeff acknowledging Abed's function as metacritic and commenting on the metacommentary - and the irritation that this may eventually cause the viewer accustomed to more traditional fare, or wary of "jumping the shark" and losing the coherence of the relative verisimilitude of believable characters to the omnipresence of television tropes. In fact, neither Jeff nor Abed can win this struggle between traditional sitcom tropes and metacommentary without changing the very nature of the sitcom, since privileging Jeff's position would be to relinquish the unique nature of the sitcom, and privileging Abed's would in effect relinquish the sitcom altogether, where all coherency is lost in the constant search for more tropes, more genres to parody. Though the writers initially discussed Abed's function as being more realistic, allowing the viewer to acknowledge that the characters know popular culture references the same way that any real person would, when in an episode entitled "Messianic Myth and Ancient Cultures" Abed is given the task of coming up with a viral video with a Christian message, he quickly decides to make a metafictional film:

ABED: [...] the story's been told to death, so I want to approach it in a new way. We need a Jesus movie for the post-postmodern world. [...] I want to tell the story of Jesus from the perspective of a filmmaker exploring the life of Jesus.

SHIRLEY: That sounds... very appealing to filmmakers.

ABED: See, in the filmmaker's film, Jesus is a filmmaker trying to find God with his camera. But then the filmmaker realizes that he is actually Jesus, and he's being filmed by God's camera, and it goes like that forever in both directions like a mirror in a mirror, "cause all the filmmakers are Jesus and all the cameras are God. And the movie's called "Abed". All caps. Filmmaking beyond film. A meta-film. My masterpiece.

SHIRLEY: I don't like it.

ABED: Well, that's OK. You're reacting the way the world did to Jesus.

SHIRLEY: I'm reacting the way the world does to movies about making movies about making movies. I mean, come on, Charlie Kaufman, some of us have to work in the morning, damn! (2.5, 4:48-5:40)

His film involves the entire campus, faculty and students alike, who eventually are unable to distinguish between fiction and reality; a student remarks "I heard the deleted scenes are the scenes, and the scenes are the deleted scenes" (2.5, 8:50-8:52), while Abed intones that the entire world is one long take. Abed eventually realizes that the film is "complete crap", thus demonstrating the risks of pure metafiction. 
In the end, the fact that Abed realizes his metafictional stance is untenable is crucial to a better understanding of his character, and the sitcom that he represents: after all, we are told again and again that for Abed, reference is not an end in itself, but a way to connect with others; in "Contemporary American Poultry", he exults: "I don't need to use movies or TV shows to talk to people anymore. Before I only needed them because the day-to-day world made no sense to me. But now everyone's speaking the same language: chicken.” (1.21, 10:2210:32) More emotionally, an early episode "Introduction to Film", where Abed makes his first movie while taking a film class his father refuses to pay for, reinforces the idea that film is all about expression, as it allows Abed to express his feelings about his mother leaving his father and himself, and his subsequent estrangement from his father who seems to blame him for her departure ${ }^{10}(1.3,17: 05-18: 48)$. In the end, the esthetic value of fiction is unimportant as long as it reaches its intended audience, and Abed, like the sitcom in which he is situated, will continue to straddle the fine line between generic expectations and redefining the limitations of that genre, between verisimilitude and critical commentary. In so doing, the character points out the artifices of the sitcom genre, while at the same time transforming the mundane (chicken fingers!) into the spectacular, insisting on the elements of fiction that appear in our everyday lives: through Abed, Community both reifies sitcom conventions and links them back to the spectator's own lives - making it one of the most original series in recent memory.

\footnotetext{
${ }^{10}$ Indeed, the show repeatedly emphasizes the point that Abed's pop culture references are not gratuitous, but emotionally motivated, perhaps most recently in one of the series' more subtle episodes, "Critical Film Studies", where Abed rejects the Pulp Fiction surprise birthday party Jeff has planned for him, preferring to ask him for "real conversation" in an elegant restaurant. When Jeff discovers this is in fact an homage to independent film $M y$ Dinner with Andre, he is furious, until Abed explains that his reference is rooted in his worries about their relationship: "I chose My Dinner with Andre, because it's about a guy who has an unexpectedly enjoyable evening with a weird friend he's been avoiding lately." $(2.21,17: 41)$ The Pulp Fiction evening ensues, but it is now emotionally motivated, not simply a series of pop culture references for the pleasure of it - a charge often leveled at Tarantino himself...
} 